\title{
STATUS SEDIMEN SUNGAI BREMI KABUPATEN PEKALONGAN DITINJAU DARI ASPEK KIMIA DAN BIOLOGI
}

\author{
Nurbaity Istiqomah, Frida Purwanti ${ }^{l}$, Haeruddin \\ Program Studi Manajemen Sumberdaya Perairan, Jurusan Perikanan \\ Fakultas Perikanan dan Ilmu Kelautan, Universitas Diponegoro
}

\begin{abstract}
ABSTRAK
Sepanjang aliran Sungai Bremi, terdapat banyak industri batik rumahan yang membuang limbah ke sungai sehingga Sungai Bremi tersebut mengalami penurunan kualitas perairan. Bahan pencemar yang masuk ke dalam perairan tersebut akan terakumulasi dalam sedimen, khususnya logam berat seperti kromium dan fenol. Masuknya bahan pencemar ke dalam sedimen dapat mempengaruhi organisme yang tinggal dalam sedimen. Penelitian ini bertujuan untuk mengetahui konsentrasi kromium, fenol, tekstur sedimen, struktur komunitas makrobentos, pola hubungan antara konsentrasi kromium dan fenol dengan struktur komunitas (keanekaragaman dan kelimpahan) makrobentos di Sungai Bremi, dan status sedimen Sungai Bremi ditinjau dari konsentrasi kromium, fenol, dan struktur komunitas makrobentos. Penelitian ini dilakukan pada bulan Mei-Juni 2013 di tiga stasiun.

Alat dan bahan yang digunakan dalam penelitian ini adalah sampel sedimen sungai dan sampel makrobentos. Ekman Grab digunakan untuk mengambil sampel Rose bengole digunakan untuk memberi warna pada sampel makrobentos dan formalin $4 \%$ untuk mengawetkan sampel makrobentos. Teknik pengambilan sampel menggunakan metode purposive sampling di 3 stasiun secara komposit, kemudian substrat disaring menggunakan saringan yang bermesh size $0,5 \mathrm{~mm}$. Material-material yang tertinggal kemudian dimasukkan kedalam botol sampel, setelah itu diberi formalin $4 \%$ dan 1-2 tetes rose bengole.

Hasil pengamatan menunjukkan bahwa konsentrasi kromium berkisar 3,395-8,768 ppm, fenol antara 0,0350,0623 ppm, dan fraksi sedimen dari ketiga stasiun tersebut adalah lanau berpasir. Makrobentos hanya ditemukan di stasiun I yang terdiri atas 4 spesies yakni Chironomus $s p$, Lymnea $s p$, Nereis $s p$, dan Tubifex $s p$ dengan kelimpahan sebesar $1270 \mathrm{ind} / \mathrm{m}^{3}$. Nilai indeks keanekaragamannya 0,687 , indeks keseragamannya 0,49 , dan indeks dominasinya 0,66 . Nilai koefisien korelasi (r) antara konsentrasi kromium, fenol dengan struktur komunitas berkisar 0,617-0,797. Nilai tersebut menunjukkan bahwa adanya hubungan kuat antara konsentrasi kromium, fenol dengan struktur komunitas makrobentos memiliki korelasi yang kuat. Hasil konsentrasi kromium, fenol dibandingkan dengan kriteria atau baku mutu sedimen menunjukkan bahwa sedimen Sungai Bremi dalam keadaan tercemar.
\end{abstract}

Kata kunci : Kromium, Fenol, Tekstur Sedimen, Struktur Makrobentos, Sungai Bremi

\section{ABSTRACT}

Along the Bremi River's flow, there are many batik home industries that disposed their waste to the river and would degreaded water quality. Contaminants that enter to the water will accumulate in the sediments, especially heavy metals such as chromium and phenol. Input of contaminants into sediment can affect organisms that live in the sediment. This research aims to know the concentration of chromium, phenols, sediment texture, structure of makrobentos communities, pattern of the relationship between concentration of chromium dan phenols to the community structure (diversity and abundance) of makrobentos in the Bremi River, and sediment status of The Bremi River based on concentration of chromium, phenol, and communities structure of makrobentos. This research was conducted in MayJune 2013 in three stations.

Material used in the research were sediment samples and makrobentos samples. Ekman grab was used to take sample, rose bengole was used to give the colors on sample, and $4 \%$ formalin to preserve makrobentos samples. The techniques of sample retrieval is using the method of purposive sampling at three stations in the composite, then substate filtered using a filter which has a size of $0,5 \mathrm{~mm}$. Materials that left then inserted into the sample bottle, after that it was given $4 \%$ formalin and 1-2 drops of rose bengole.

The study focus, result of chromium concentrations ranged from 3,395 to 8,768 ppm, phenol ranged from 0,035 $0,0623 \mathrm{ppm}$. sediment fraction of three stations is sandy silt. Makrobentos only found in the station I that found 4 species. There are Chironomus sp, Lymnea sp, Nereis sp, and Tubifex sp, with abundance is $1270 \mathrm{ind} / \mathrm{m}^{3}$. Diversity index values is 0,687 , uniformity index is 0,49 , and the dominance index is 0,66 . Value of the correlation coefficient (r) between the concentrations of chromium, phenol with community structure ranged from 0,617 to 0,797 . This value indicates that the relationship of chromium concentration, phenol with makrobentos community structure have a strong correlation. Result of chromium concentration, phenol compared with sediment quality/standard criteria showed that the Bremi river sediment was in the polluted state.

Keywords: Chromium, Phenol, Sediment Texture and Structure of Makrobentos Communities, Bremi River.

*) Penulis Penanggung Jawab 


\section{Pendahuluan}

Sungai atau aliran sungai merupakan jumlah air yang mengalir sepanjang lintasan di darat menuju ke laut sehingga sungai merupakan suatu lintasan dimana air yang berasal dari hulu bergabung dan menuju ke suatu yaitu hilir (muara). (Haslam, 1992 dalam Anna, 2001).

Sungai banyak digunakan manusia untuk kegiatan sehari-hari, aktivitas masyarakat tersebut dapat menimbulkan penurunan kualitas perairan. Salah satu sungai yang sudah mengalami penurunan kualitas perairan adalah Sungai Bremi di Pekalongan, di sepanjang aliran Sungai Bremi terdapat pemukiman penduduk yang banyak diantaranya bermata pencaharian sebagai pengrajin batik. Sebagai akibat dari perkembangan aktivitas manusia, seperti adanya aktivitas perindustrian yang berdiri disekitar daerah aliran sungai dapat mempengaruhi kualitas perairan. Penurunan kualitas perairan dapat dilihat dari warna sungainya berwarna hitam pekat, dan memiliki bau yang tidak sedap.

Penurunan kualitas perairan diduga adanya limbah hasil kegiatan masyarakat yang berasal dari kegiatan rumah tangga, industri batik rumahan dan kegiatan pertambakan yang masuk kedalam aliran sungai. Limbah tersebut dapat mengandung berbagai macam bahan kimia yang digunakan selama proses produksi, salah satunya kromium $(\mathrm{Cr})$, dan fenol karena bahan pencemar tersebut digunakan pada proses pewarnaan dan pencetakan. Limbah domestik dan limbah tekstil yang dibuang langsung ke aliran sungai tersebut menyebabkan warna air berubah menjadi keruh dan pekat, dan menimbulkan bau tak sedap serta menurunkan tingkat kebersihan air. Bahan pencemar tersebut akan terakumulasi dalam sedimen dan akan berpengaruh terhadap penurunan kualitas perairan. Sedimen, merupakan habitat bagi banyak organisme bentik dan dalam lingkungan perairan sebagian besar buangan limbah yang masuk kedalam perairan. Limbah tersebut secara langsung maupun tidak langsung dapat mengganggu keseimbangan ekosistem sungai, ketidakseimbangan dalam ekosistem sungai otomatis akan berpengaruh terhadap biota yang hidupnya menetap.

Hewan makrobentos adalah organisme yang hidupnya menetap di dasar perairan dan mempunyai pergerakan yang sangat lamban. Kelompok hewan ini dapat digunakan sebagai indikator pencemaran perairan.Apabila terjadi perubahan lingkungan yang diakibatkan oleh pencemaran, maka hewan makrobentos tidak berpindah menuju daerah yang sesuai untuk kelangsungan hidupnya. Hewan makrobentos relatif mudah diidentifikasi, apabila pencemaran meningkat maka akan mempengaruhi jumlah dari spesies yang ada, sebab hanya beberapa spesies atau spesies tertentu yang dapat bertahan (Winarni, 2002 dalam Ulfah, 2012).

Tujuan penelitian ini adalah untuk mengetahui konsentrasi kromium, fenol, tekstur sedimen, struktur komunitas makrobentos, pola hubungan antara konsentrasi kromium dan fenol dengan struktur komunitas (keanekaragaman dan kelimpahan) makrobentos di Sungai Bremi, dan status sedimen Sungai Bremi ditinjau dari konsentrasi kromium, fenol, dan struktur komunitas makrobentos. Penelitian ini dilakukan pada bulan Mei-Juni 2013 di Sungai Bremi. Identifikasi makrobentos dilakukan di Laboratorium Manajemen Sumberdaya Perairan FPIK Universitas Diponegoro Semarang. Analisa Kromium, Fenol di Laboratorium Wahana, Semarang. Analisa tekstur sedimen di Laboratorium Mekanika Tanah, Fakultas Teknik Sipil, Universitas Diponegoro Semarang.

\section{Materi dan Metode Penelitian}

\section{A. Materi Penelitian}

Materi yang digunakan dalam penelitian ini di Sungai Bremi adalah sampel sedimen dan sampel makrobentos. Alat-alat yang digunakan dalam penelitian ini adalah water quality checker untuk mengukur $\mathrm{pH}, \mathrm{DO}$, dan suhu, seschi disc untuk mengukur kecerahan, GPS untuk mengetahui koordinat titik sampling, bola arus untuk mengukur arus, Ekman Grab untuk mengambil sedimen, , kantong plastik untuk tempat sampel, saringan bentos untuk menyaring bentos, mikroskop untuk mengidentifikasi makrobentos, buku identifikasi makrobentos untuk mengidentifikasi makrobentos, petridis untuk menampung sampel, Slide glass untuk mengamati sampel, dan kamera digital untuk dokumentasi. Bahan yang digunakan adalah Rose Bengole untuk pemberi warna pada sampel, Formalin untuk mengawetkan sampel.

\section{B. Metode Penelitian}

Metode penelitian ini menggunakan metode survei. Metode survei merupakan metode penelitian yang dilakukan untuk memperoleh fakta-fakta dari gejala yang terdapat di lapangan dan mencari informasi yang faktual. Metode penelitian ini dilakukan pada sekumpulan obyek dan berasumsi bahwa obyek yang telah diteliti telah mewakili populasi yang diamati (Hasan, 2004).

\section{Lokasi sampling}

Sungai yang dimaksud dalam metode penelitian ini adalah perairan yang tawar atau bersalinitas $0 \%$.

\section{Penentuan titik sampling}

Lokasi pengambilan sampel pada penelitian ini dilakukan di sungai dan muara Sungai Wedung. Pengambilan sampel dilakukan pada 6 titik di tiap-tiap lokasi dengan sejajar lebar sungai. Penelitian ini dilakukan selama 28 hari dengan interval waktu 1 minggu sekali. Stasiun yang diukur adalah sebagai berikut: 
1. Titik 1

berada di hulu sungai dimana daerah perairan tersebut belum mengalami pencemaran limbah batik dan domestik, jarak dari stasiun I ke stasiun II \pm 4 kilometer.

2. Titik 2

Berada di bagian tengah Sungai Bremi diantara titik hulu dan titik hilir berjarak 3 kilometer dari stasiun III yang merupakan daerah perairan yang sedang tercemar limbah batik dan domestik.

3. Titik 3

Berada di hilir sungai dengan jarak 1 kilometer dari.

Metode sampling

\section{a. Metode pengambilan sampel sedimen dan makrobentos}

Metode pengambilan sampel sedimen dan makrobentos dilakukan dengan menggunakan Ekman Grab, dengan cara komposit berdasarkan tempat yaitu pada dua titik di tepi masing-masing bagian kanan dan kiri badan air serta bagian tengah badan air.

1. Mengambil sampel sedimen secara gabungan (komposit) dengan menggunakan Ekman Grab,

2. Substrat yang tersangkut disaring menggunakan saringan yang bermesh size $0,5 \mathrm{~mm}$.

3. Material-material yang tertinggal ditampung dalam botol sampel yang diberi label kemudian diawetkan dengan formalin $4 \%$, untuk memudahkan pemisahan hewan makrobentos dengan detritus,

4. Sampel diberi beberapa tetes larutan rose bengole

\section{b. Analisa tekstur sedimen}

Analisa tekstur sedimen menggunakan metode analisa hidrometer kemudian dilanjutkan dengan analisis saringan.

1. Sampel kering yang sudah dioven selama 24 jam diambil sebanyak 50 gr.

2. Sampel diberi sodium silikat $15 \mathrm{cc}$ dan aquades secukupnya, kemudian diamkan selama 24 jam.

3. Sampel tersebut dimasukkan kedalam mixer dan diberi aquades secukupnya kemudian diaduk selama 15 menit sampai homogen.

4. Sampel yang sudah dimixer tadi dimasukkan ke dalam gelas ukur 1000cc, kemudian gelas ukur tersebut ditutup dengan plastik dan didiamkan selama 24 jam.

5. Suspensi tersebut dikocok-kocok sampai benar-benar homogen selama1 menit.

6. Gelas ukur diletakkan pada meja yang datar, alat seperti stopwatch disiapkan, selanjutnya alat hidometer dimasukkan kedalam gelas ukur bersama thermometer, dan pembacaan alat hidometer juga suhu dilakukan pada menit ke 1, 2, 5, 15, 30, 60, 240, dan 1440.

7. Setelah selesai, suspensi dicuci dalam saringan dengan $\mathrm{D}=0,074 \mathrm{~mm}$, hasil cucian dioven dan ditimbang, kemudian disaring dalam susunan saringan, selanjutnya dilakukan percobaan analisis saringan

\section{c. Analisa Kromium}

Analisa kandungan logam kromium menggunakan metode ekstraksi asam :

1. Pengukuran berat kering sampel, dimana sampel dipanaskan hingga temperatur $60^{\circ} \mathrm{C}$.

2. Temperatur tersebut dibuat tidak terlalu tinggi untuk mencegah penguapan logam berat.

3. Berat konsentrasi logam berat dalam sampel diukur setelah proses preparasi (ekstraksi) dengan penambahan $10 \mathrm{ml}$ aqua regia $\left(3\right.$ bagian $\mathrm{HNO}_{3}+1$ bagian $\mathrm{HCl}$ ) pada \pm 2 gram sampel dan ditutup dengan gelas arloji.

4. Setelah sampel larut, dilakukan penambahan $\mathrm{H}_{2} \mathrm{O}_{2}$. Pada akhir proses ekstraksi tersebut, dilakukan penyaringan larutan sampel ke dalam labu takar $50 \mathrm{ml}$, diencerkan hingga mencapai tanda $50 \mathrm{ml}$. Kemudian, dilanjutkan dengan pengukuran logam berat menggunakan AAS tipe flame.

\section{d. Analisa Fenol}

1. Ekstraksi Sebanyak 20 gram sampel yang telah dimasukkan ke dalam thimble diekstraksi soxhlet menggunakan $100 \mathrm{ml}$ pelarut metilenklorida $(\mathrm{CH} 3 \mathrm{Cl})$ selama 8 jam (American Society for Testing and Materials, Nomor D.5369-93, 2003).

2. Penentuan kadar fenol total dalam sampel dilakukan dengan menguapkan pelarut (metilenklorida) dengan rotary evaporator sehingga diperoleh ekstrak fenol.

3. Tambahkan aquadest sampai $10 \mathrm{ml}$ kemudian di homogenisasikan selama 30 detik. Selanjutnya ditambahkan reagen folin-ciocalteau sebanyak $0,2 \mathrm{ml}$ dan karbonat-tartrat sebanyak $2 \mathrm{ml}$

4. Campuran di homogenisasikan kembali dan kemudian dibiarkan pada suhu kamar atau ambient temperatur selama 30 menit (Widadi, 2005). Percobaan ini dilakukan dengan dua kali pengulangan, kemudian dianalisis dengan Spektrofotometer pada panjang gelombang $740 \mathrm{~nm}$.

\section{e. Metode pengukuran kualitas air}

Metode pengukuran kualitas air dilakukan di setiap titik sampling dengan melakukan tiga kali pengulangan di setiap pengukuran. Tahap - tahap pengukuran kualitas air :

1. Pengukuran DO dengan menggunakan water quality checker diukur pada setiap titik lokasi pengambilan sampel, dengan cara memasukkan sensor ke dalam perairan kemudian ditunggu sampai skalanya stabil. 
2. Pengukuran suhu dengan menggunakan water quality checker diukur pada setiap titik lokasi pengambilan sampel, dengan cara memasukkan sensor ke dalam perairan kemudian ditunggu sampai skalanya stabil.

3. Pengukuran $\mathrm{pH}$ dengan menggunakan water quality checker diukur pada setiap titik lokasi pengambilan sampel, dengan cara memasukkan sensor ke dalam perairan kemudian ditunggu sampai skalanya stabil.

4. Pengkuran kecerahan : pada setiap titik lokasi pengambilan sampel dengan menggunakan Secchi disk. Secchi disk dimasukan ke dalam perairan kemudian dilihat skala dimana Secchi disk masih terlihat jelas (K1) dan skala dimana Secchi disk terlihat remang-remang (K2). Menurut Effendi (2003), persamaan untuk mengukur kecerahan sebagai berikut :

Keterangan:

$$
\mathrm{D}=\frac{\mathrm{K} 1+\mathrm{K} 2}{2}
$$

$\mathrm{D}=$ Kecerahan $(\mathrm{cm})$

$\mathrm{K} 1=$ Secchi disk masih terlihat jelas $(\mathrm{cm})$

$\mathrm{K} 2$ = Secchi disk terlihat remang-remang $(\mathrm{cm})$

\section{Hasil dan Pembahasan}

\section{Gambaran umum lokasi penelitian}

Lokasi penelitian berada di perairan Sungai Bremi Kabupaten Pekalongan. Sungai Bremi merupakan sungai yang mengalir diantara perbatasan Kota Pekalongan dengan Kabupaten Pekalongan. Secara administratif wilayah Kota Pekalongan terdiri dari:

1. Sebelah Utara adalah Laut Jawa

2. Sebelah Selatan adalah Kabupaten Pekalongan dan Kabupaten Batang

3. Sebelah Timur adalah Kabupaten Pekalongan

4. Sebelah Barat adalah Kabupaten Batang

Sungai Bremi memiliki panjang $9 \mathrm{~km}$ dan kecamatan Tirto merupakan kecamatan yang dilalui Sungai Bremi (Rahmawati et al, 2008). Aliran sungai yang melalui lokasi stasiun I melewati daerah Kotamadya Pekalongan. Pengambilan sampel terletak di desa Jenggot, di desa tersebut terdapat pabrik batik printing yang berada di sekitar pemukiman warga. Stasiun I disekitarnya terdapat lahan-lahan kosong, karena pada daerah tersebut memiliki sedikit jumlah pemukiman di sekitar sungai.Stasiun I memiliki warna air coklat dan substrat berwarna abu-abu. Stasiun II terletak di desa Pasirsari, di desa tersebut terdapat lebih banyak industri rumah tangga berupa batik cap dan perumahan warga yang lebih padat. Stasiun II memiliki warna perairan dan warna substrat yaitu hitam pekat, dan memiliki bau yang tidak sedap. Stasiun III berada di dekat muara, memiliki warna perairan yang tidak terlalu hitam pekat, dan terdapat area pertambakan bandeng di sekitar sungai.

\section{Hasil Konsentrasi logam kromium (Cr), fenol dalam sedimen, dan tekstur sedimen}

a. Kromium

Hasil analisa kandungan kromium di lokasi penelitian adalah sebagai berikut :

Tabel 1. Rata-rata Konsentrasi Logam Kromium (Cr)

\begin{tabular}{ccccc}
\hline Stasiun & Kromium $(\mathrm{ppm})$ & SD & Ambang batas & Pustaka \\
\hline I & 3,395 & 0,35 & $0,09-0,65 \mathrm{ppm}$ & Sudaryanto (2001) \\
II & 8,768 & 0,44 & & \\
III & 5,026 & 0,23 & & \\
\hline
\end{tabular}

\section{b. Fenol}

Hasil analisa kandungan fenol di lokasi penelitian adalah sebagai berikut :

Tabel 2. Rata-rata Konsentrasi Fenol

\begin{tabular}{ccccc}
\hline Stasiun & Fenol $(\mathrm{ppm})$ & SD & Ambang batas & Pustaka \\
\hline I & 0,035 & 0,003 & $0,21 \mathrm{ppm}$ & ATSDR, 2006 \\
II & 0,0623 & 0,006 & & \\
III & 0,0416 & 0,003 & & \\
\hline
\end{tabular}

\section{c. Tekstur Sedimen}

Berdasarkan hasil pengamatan, fraksi sedimen dari ketiga stasiun diperoleh tipe substrat Lanau Pasiran, fraksi sedimen tersebut tersaji pada Tabel 3.

Tabel 3. Hasil Pengamatan Fraksi Sedimen di Sungai Bremi

\begin{tabular}{cccccc}
\hline Stasiun & Kerikil (\%) & Pasir (\%) & Lanau (\%) & Lempung (\%) & Kriteria \\
\hline I & 1,40 & 41,80 & 51,37 & 5,43 & Lanau Berpasir \\
II & 1,80 & 34,60 & 58,17 & 5,43 & Lanau Berpasir \\
III & 3,20 & 40,10 & 52,63 & 4,07 & Lanau Berpasir \\
\hline
\end{tabular}


Hasil Struktur komunitas makrobentos

Berdasarkan hasil pengamatan makrobentos didapatkan 4 spesies yaitu Chironomus sp, Tubifex sp, dan Lymnea sp, Nereis sp. Data kelimpahan individu dan kelimpahan relatif tersaji pada tabel dibawah ini

Tabel 4. Hasil Kelimpahan Individu Makrobentos di Sungai Bremi Kabupaten Pekalongan

\begin{tabular}{|c|c|c|c|c|c|c|c|c|c|}
\hline \multirow{3}{*}{ Biota } & \multicolumn{9}{|c|}{ Stasiun } \\
\hline & \multicolumn{3}{|c|}{$\mathrm{I}$} & \multicolumn{3}{|c|}{ II } & \multicolumn{3}{|c|}{ III } \\
\hline & 1 & 2 & 3 & 1 & 2 & 3 & 1 & 2 & 3 \\
\hline \multicolumn{10}{|l|}{ Diptera } \\
\hline Chironomus sp. & 2 & 10 & 0 & 0 & 0 & 0 & 0 & 0 & 0 \\
\hline \multicolumn{10}{|l|}{ Gastropoda } \\
\hline Lymnaea sp. & 6 & 0 & 11 & 0 & 0 & 0 & 0 & 0 & 0 \\
\hline \multicolumn{10}{|l|}{ Polychaeta } \\
\hline Nereis sp. & 4 & 3 & 0 & 0 & 0 & 0 & 0 & 0 & 0 \\
\hline \multicolumn{10}{|l|}{ Oligochaeta } \\
\hline Tubifex sp. & 58 & 22 & 67 & 0 & 0 & 0 & 0 & 0 & 0 \\
\hline Jumlah & 70 & 35 & 78 & 0 & 0 & 0 & 0 & 0 & 0 \\
\hline Total & & 183 & & & 0 & & & 0 & \\
\hline Kelimpahan (ind $/ \mathrm{m}^{3}$ ) & & 1270 & & & 0 & & & 0 & \\
\hline Indeks Keanekaragaman (H') & & 0,687 & & & 0 & & & 0 & \\
\hline Indeks Keseragaman (E) & & 0,49 & & & 0 & & & 0 & \\
\hline Indeks Dominasi (D) & & 0,66 & & & 0 & & & 0 & \\
\hline
\end{tabular}

Hasil Hubungan antara kromium, fenol, dan struktur komunitas makrobentos

Berdasarkan hasil analisa hubungan Kromium, Fenol dengan struktur komunitas makrobentos dengan menggunakan software Curve expert 1.3, didapatkan hasil sebagai berikut:

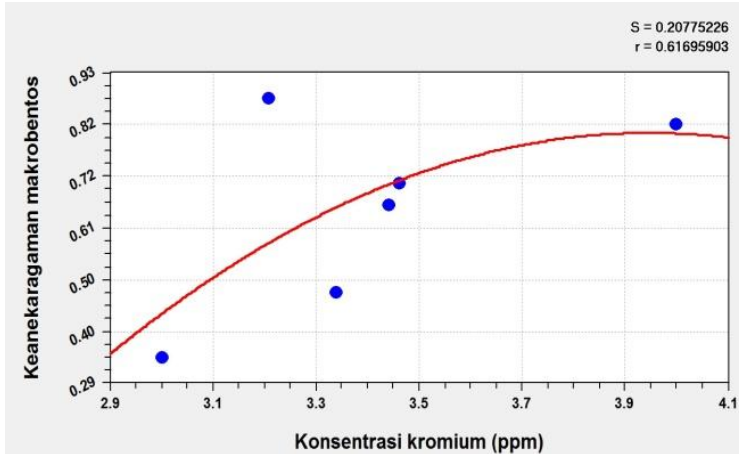

Gambar 1. Grafik Hubungan antara Konsentrasi Kromium dengan Keanekaragaman Makrobentos

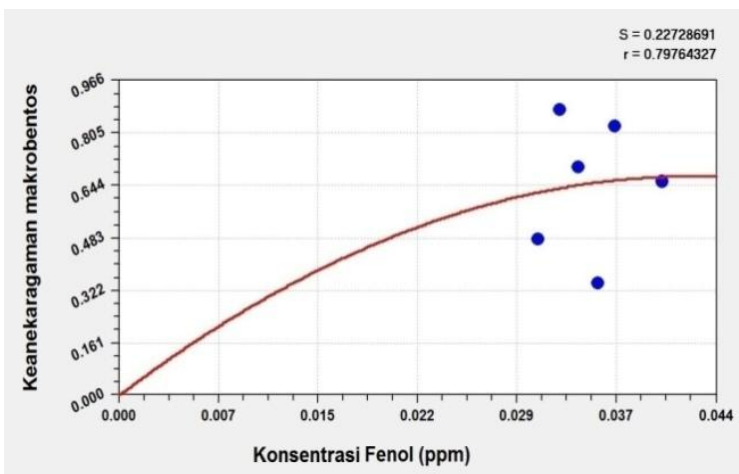

Gambar 3. Grafik Hubungan antara Konsentrasi Fenol dengan Keanekaragaman Makrobentos

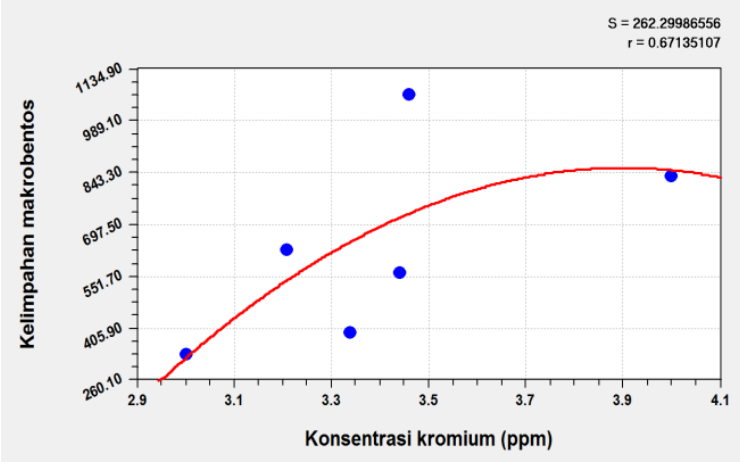

Gambar 2. Grafik Hubungan antara Konsentrasi Kromium dengan Kelimpahan Makrobentos

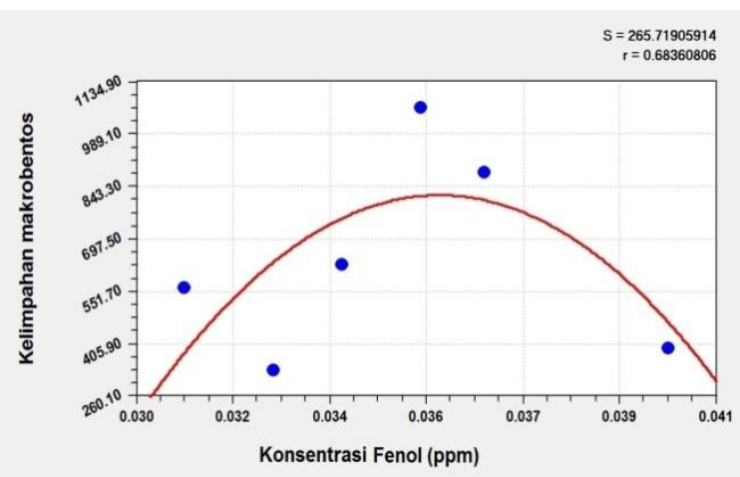

Gambar 5. Grafik Hubungan Antara Konsentrasi Fenol dengan Kelimpahan Makrobentos 
Penetapan status sedimen

Penetapan status sedimen dengan membandingkan konsentrasi kromium, fenol dan struktur makrobentos dilihat dari indeks keanekaragaman dan kelimpahan tersaji pada Tabel 5 sebagai berikut:

Tabel 5. Penetepan Status Sedimen Berdasarkan Aspek Kimia dan Biologi

\begin{tabular}{lcccc}
\hline Aspek Kimia dan Biologi & Hasil & Status & Ambang batas & Pustaka \\
\hline Kromium & $3,395-8,768 \mathrm{ppm}$ & Tercemar & $0,09-0,65 \mathrm{ppm}$ & Sudaryanto (2001) \\
Fenol & $0,035-0,0623 \mathrm{ppm}$ & Tidak tercemar & $0,21 \mathrm{ppm}$ & ATSDR (2006) \\
Keanekaragaman & $0,343-0,878$ & Tercemar & $0<\mathrm{H}^{\prime}<2,302$ & Odum (1996) \\
Kelimpahan & $333-1062 \mathrm{ind} / \mathrm{m}^{3}$ & Komposisi sedang & $<500 \mathrm{ind} / \mathrm{m}^{2}$ & Sudaryanto (2001) \\
\hline
\end{tabular}

Hasil Parameter Kualitas Air

Berdasarkan hasil pengamatan kualitas air di Sungai Bremi didapatkan hasil sebagai berikut:

Tabel 6. Rata-rata dan Standar Deviasi Parameter Kualitas Air

\begin{tabular}{lcccccc}
\hline \multirow{2}{*}{ Parameter Kualitas Air } & \multicolumn{7}{c}{ Stasiun } \\
\cline { 2 - 7 } & I & SD & II & SD & III & SD \\
\hline Suhu Air $\left({ }^{\circ} \mathrm{C}\right)$ & 26,8 & 0,216 & 30,7 & 0,574 & 30,4 & 0,542 \\
Suhu Udara $\left({ }^{\circ} \mathrm{C}\right)$ & 27,6 & 0,516 & 31,6 & 0,516 & 31 & 0 \\
Kedalaman $(\mathrm{m})$ & 0,87 & 0,076 & 1,39 & 0,432 & 1,17 & 0,372 \\
Kecepatan Arus $(\mathrm{m} / \mathrm{s})$ & 0,019 & 0,001 & 0,047 & 0,015 & 0,073 & 0,028 \\
Kecerahan $(\mathrm{m})$ & 0,26 & 0,033 & 0,15 & 0,056 & 0,17 & 0,034 \\
$\mathrm{pH}$ & 4,46 & 0,542 & 3,95 & 0,677 & 3,83 & 0,339 \\
DO (mg/l) & 2,44 & 0,687 & 1,93 & 0,559 & 2,03 & 0,406 \\
\hline
\end{tabular}

Pembahasan

Berdasarkan hasil pengujian laboratorium, nilai konsentrasi kromium pada stasiun I memiliki ratarata sebesar 3,395 ppm, stasiun II sebesar 8,768 ppm, dan pada stasiun III sebesar 5,026 ppm. Hasil pengamatan stasiun I konsentrasi fenol rata-rata $0,035 \mathrm{ppm}$, stasiun II sebesar 0,0623 ppm, dan pada stasiun III sebesar 0,0416 ppm. Kandungan kromium dan fenol dengan nilai yang paling tinggi dalam sampel sedimen ditemukan pada stasiun II dibanding pada stasiun I dan III, karena pada stasiun II merupakan titik pusat pembuatan industri rumahan batik dan pembuangan limbah batik sehingga mempengaruhi nilai kromium dan fenol lebih besar dibanding stasiun I dan III. Stasiun I nilai kromium sudah melewati ambang batas hal ini diduga karena adanya pencucian batik dan jeans di stasiun tersebut.

Hal ini sesuai dengan hasil penelitian Mance (1987) dalam Apriadi (2005), yang mengatakan bahwa konsentrasi logam berat di sedimen jauh lebih tinggi jika dibandingkan dengan yang ada pada kolom perairan. Hal ini disebabkan logam berat yang masuk ke dalam kolom perairan akan diserap oleh partikelpartikel tersuspensi.

Hasil pengamatan tipe sedimen pada ketiga stasiun adalah lanau berpasir, hal ini dikarenakan jumlah persentase lanau dan pasir dari ketiga stasiun lebih besar daripada fraksi kerikil dan lempung. Stasiun I dan II memiliki persentase lanau sebesar 5,43\% dibandingkan stasiun III. Stasiun I memiliki persetase pasir lebih tinggi sebesar $41,80 \%$ dibandingkan dengan II dan III. Stasiun II memiliki persentase lempung lebih besar dibanding dengan pada stasiun I atau stasiun III sebesar 58,17\%. Stasiun III atau hilir sungai jumlah persentase kerikil lebih besar diantara stasiun I dan stasiun II yakni 3,20\%.

Lanau atau lumpur halus (Fine silt) merupakan peralihan tanah lempung dengan pasir halus, memiliki tekstur yang lembut, biasanya berwarna kelabu, bila dikepal dan dilepaskan tidak mengumpal seperti lumpur. Perbedaan tipe sedimen akan mempengaruhi akumulasi logam berat ke dalam sedimen dan mempengaruhi jenis biota yang tinggal di dalam sedimen. Tipe substrat berpasir halus kurang baik bagi pertumbuhan organisme perairan karena memiliki pertukaran masa air yang lambat, kadar oksigen yang rendah dan dapat menyebabkan keadaan anosik sehingga proses dekomposisi yang berlangsung di substrat pada keadaan anaerobik dapat mengakibatkan bau serta tercemarnya perairan (Nybakken, 1992).

Banyaknya kandungan kromium disebabkan sifat akumulatif dengan jangka waktu yang lama dan terus-menerus pada sedimen yang mempunyai sifat relatif menetap, tidak bergerak sehingga pada stasiun II dan III tidak ditemukannya biota.Hal tersebut sesuai dengan pernyataan Korzeniewski dan Neugabieuer (1991) dalam Kaban (2010) karena konsentrasi logam berat meningkat seiring dengan semakin halusnya sedimen.

Rendahnya komposisi struktur makrobentos di Sungai Bremi menunjukkan telah terjadinya sesuatu terhadap ekosistem sehingga menyebabkan tekanan terhadap lingkungan. Organisme sangat sensitif terhadap gangguan habitat seperti terkontaminasinya sedimen oleh bahan beracun sepertihalnya logam berat, ataupun melimpahnya bahan organik. Menurut Daeur (1987) dalam Sudaryanto (2001), tekanan bahan pencemar yang akut seringkali mengakibatkan kematian dan spesies yang sangat sensitif secara mudah akan hilang dari komunitas. 
Hasil dari sampling yang telah dilakukan di Sungai Bremi pada stasiun I telah ditemukannya hewan bentos yakni diantaranya adalah Chironomus sp, Tubifex sp, Nereis sp, dan Lymnaea sp, sedangkan pada stasiun II dan III tidak ditemukan hewan bentos, hal ini diduga karena nilai kromium dan fenol di stasiun I masih dapat ditolerir yakni kromium dengan rata-rata $3,395 \mathrm{ppm}$, dan fenol dengan rata-rata $0,035 \mathrm{ppm}$, sedangkan pada stasiun II dan III nilai konsentrasi kromium dan fenol lebih tinggi dibanding stasiun I. Nilai konsentrasi kromium pada stasiun II dan III berkisar 5,026-8,768 ppm dan nilai konsentrasi fenol pada stasiun II dan III berkisar 0,0416-0,0623 ppm, hal ini diduga biota tersebut tidak dapat mentolerir nilai kromium dan fenol yang tinggi sehingga pada stasiun II dan III tidak ditemukan adanya hewan bentos.

Hasil dari perhitungan struktur makrobentos pada samplingdiperoleh nilai indeks keanekaragaman $\left(\mathrm{H}^{\prime}\right)$ sebesar 0,687. Nilai tersebut menunjukkan keanekaragaman makrobentos di Sungai Bremi tergolong rendah, hal ini diperkuat oleh pernyataan Brower et al, (1990) dalam Mutia (2007) dimana nilai keanekargaman yang berada dibawah 3,32 menunjukkan keanekaragaman rendah, penyebaran jumlah individu tiap spesies rendah dan kestabilan komunitas rendah.

Nilai indeks keseragaman makrobentos (E) menunjukkan nilai sebesar 0,49. Nilai tersebut menunjukkan bahwa penyebaran jumlah tiap spesies tidak merata (ada spesies yang mendominasi), dan untuk nilai indeks dominasi (D) didapatkan hasil sebesar 0,66. Hal ini diperkuat dengan pernyataan Odum (1996) semakin kecil nilai e, maka nilai indeks dominasi akan mendekati 1, artinya semakin kecil keseragaman suatu populasinya, penyebaran jumlah individu tiap spesies tidak sama atau ada kecenderungan satu spesies yang mendominasi, dari hasil yang telah didapat memang di Sungai Bremi ditemukkan adanya dominasi yaitu spesies Tubifex. Spesies Tubifex sp di Sungai Bremi ditemukan paling banyak diantara spesies lainnya, karena kelimpahan relatif Tubifex berkisar $80,8 \%$. Nilai ini lebih besar dibandingkan dengan kelimpahan individu makrobentos lainnya yakni Chironomus sp sebesar 6,5\%, Nereis sp sebesar 3,8\%, dan Lymnaea sp sebesar 9,2\%.

Rendahnya komposisi struktur makrobentos di Sungai Bremi menunjukkan telah terjadinya sesuatu terhadap ekosistem sehingga menyebabkan tekanan terhadap lingkungan. Organisme sangat sensitif terhadap gangguan habitat seperti terkontaminasinya sedimen oleh bahan beracun seperti halnya logam berat, ataupun melimpahnya bahan organik. Menurut Daeur (1987) dalam Sudaryanto (2001), tekanan bahan pencemar yang akut seringkali mengakibatkan kematian dan spesies yang sangat sensitif secara mudah akan hilang dari komunitas.

Berdasarkan hasil yang diperoleh dari analisa regresi menggunakan curva expert 1.3 pola hubungan antara konsentrasi kromium dengan keanekaragaman makrobentos didapatkan persamaan $\mathrm{Y}=-5,203+3,039 \mathrm{X}-0,384 \mathrm{X}^{2}$ dengan korelasi (r) 0,617 . Nilai koefisien determinasi antara konsentrasi kromium dengan keanekaragaman makrobentos 0,38 , hal tersebut menunjukkan konsentrasi tersebut memiliki pengaruh sebesar 38\% terhadap H' (keanekaragaman) makrobentos, sedangkan $62 \%$ dipengaruhi faktor lain.

Hubungan antara konsentrasi kromium dengan kelimpahan makrobentos didapati persamaan $\mathrm{Y}=-8619,5759+4863,7785 \mathrm{X}-624,17988 \mathrm{X}^{2}$ korelasi (r) sebesar 0,671. Nilai koefisien determinasi antara konsentrasi kromium dengan kelimpahan makrobentos 0,45 , hal tersebut menunjukkan konsentrasi tersebut memiliki pengaruh sebesar 45\% terhadap N (kelimpahan) makrobentos, sedangkan 54\% dipengaruhi faktor lain.

Pola hubungan antara konsentrasi fenol dengan keanekaragaman makrobentos didapati persamaan $\mathrm{Y}=-0,72049023+31.524413 \mathrm{X}-0,36915403 \mathrm{X}^{2}$ dengan nilai korelasi (r) 0,797 . Nilai koefisien determinasi antara konsentrasi fenol dengan $\mathrm{H}^{\prime}$ makrobentos 0,63 , hal tersebut menunjukkan konsentrasi tersebut memiliki pengaruh sebesar $63 \%$ terhadap keanekaragaman makrobentos, sedangkan $37 \%$ dipengaruhi faktor lain.

Pola hubungan antara konsentrasi fenol dengan keanekaragaman makrobentos didapati persamaan korelasi (r) sebesar 0,68 dan koefisien determinasi $\left(R^{2}\right)$ sebesar 0,46 dengan persamaan $Y=-23026,937+$ $1330618,2 X-18562902 X^{2}$ nilai korelasi (r) 0,68 . Nilai koefisien determinasi antara konsentrasi fenol dengan kelimpahan makrobentos 0,46 , hal tersebut menunjukkan konsentrasi tersebut memiliki pengaruh sebesar $46 \%$ terhadap N (kelimpahan) makrobentos, sedangkan 54\% dipengaruhi faktor lain.

Keseluruhan grafik tersebut menunjukkan adanya korelasi yang kuat. Menurut Hadi (2004) apabila korelasi sebesar 0,6-0,8 menandakan bahwa terdapat korelasi yang kuat. Menandakan adanya antara grafik kromium dengan kelimpahan ataupun keanekaragaman makrobentos, juga fenol dengan kelimpahan ataupun keanekargaman makrobentos tersebut ada kecendrungan garis menurun, sehingga pada grafik tersebut menandakan semakin tinggi kromium dan fenol dapat mempengaruhi kelimpahan dan keanekaragaman makrobentos yang semakin sedikit.

Penetapan status sedimen dilihat dari konsentrasi kromium, fenol, dan struktur makrobentos menunjukankonsentrasi kromium yang berkisar 3,203-9,117 ppm, menurut Mansyur (1982) dalam Sudaryanto (2001) nilai ambang batas kromium antara 0,09-0,65 ppm. Konsentrasi Kromium di ketiga stasiun tersebut sudah melewati ambang batas sehingga dapat dikatakan bahwa sedimen di Sungai Bremi telah tercemar dengan logam kromium. Konsentrasi fenol memiliki kisaran 0,034-0,878 ppm, menurut 
ATSDR (Agency for Toxic Substance and Disease Registry) (2006) menyatakan bahwa nilai konsentrasi maksimum fenol dalam sedimen sebesar 0,21 ppm. Konsentrasi fenol di ketiga stasiun masih dibawah ambang batas, sehingga dapat dikatakan fenol dalam sedimen Sungai Bremi masih belum tercemar fenol.

Struktur makrobentos dilihat dari keanekaragaman berkisar 0,343-0,878, menurut Odum (1996), menyatakan bahwa keanekaragaman yang rendah $\left(0<\mathrm{H}^{\prime}<2,302\right)$ menunjukkan bahwa dalam komunitas tersebut terjadi tekanan dan stress. Struktur makrobentos dilihat dari kelimpahan memiliki kisaran 333-1026 $\mathrm{ind} / \mathrm{m}^{3}$, menurut Kastoro (1990) dalam Sudaryanto (2001) kelimpahan individu di bawah 500 individu/ ${ }^{2}$ mengindikasikan komposisi kelimpahan spesies sedang. Dilihat dari keanekaragaman dan kelimpahan makrobentos menunjukkan bahwa struktur makrobentos rendah dan spesies ada yang mendominasi di Sungai Bremi.

Data parameter kualitas perairan yang diperoleh pada aliran Sungai Bremi, suhu air berkisar antara $26,8-30,7^{\circ} \mathrm{C}$. Menurut Syamsudin dan Komar (1982), dalam Ariani (2012) suhu air yang berkisar antara $20^{\circ} \mathrm{C}$ s/d $30^{\circ} \mathrm{C}$ masih cukup baik bagi kehidupan akuatik, dengan demikian suhu tersebut masih dapat ditoleransi oleh organisme akuatik. Arus rata-rata berkisar antara 0,019-0,073 m/s. menandakan bahwa kecepatan arus di Sungai Bremi lambat. Arus yang lambat membawa partikel endapan yang halus, sehingga di ketiga stasiun tersebut memiliki tekstur lanau berpasir. Kecepatan arus secara langsung atau tidak langsung mempengaruhi keadaan substrat dasar yang dapat menentukan komunitas bentos. Stasiun pertama dan kedua laju aliran arusnya lebih rendah daripada stasiun ketiga karena stasiun ketiga lebih dekat dengan muara sehingga volume sungai lebih besar daripada stasiun pertama dan stasiun kedua.

Hasil pengukuran $\mathrm{pH}$ pada tiap stasiun berkisar 3,83-4,46. $\mathrm{pH}$ sungai Bremi tergolong rendah dan termasuk ke dalam perairan asam, perairan yang asamcenderung akan mengganggu biota yang tinggal di dalam perairan daisa menyebabkan kematian.Menurut Miller and Litsky (1976) dalam Wiryanto (1997), perairan yang mempunyai kisaran $\mathrm{pH}$ 7-8 dapat menyokong kehidupan akuatik yang beraneka ragam. Nilai kecerahan berdasarkan pengukuran berkisar rata-rata antara 0,15-0,26. Nilai kecerahan suatu perairan berhubungan erat dengan penetrasi cahaya matahari ke dalam badan air. Kecerahan suatu perairan sangat dipengaruhi oleh beberapa faktor, diantaranya kedalaman perairan, cuaca (sinar matahari) serta adanya zatzat terlarut yang berada di perairan tersebut. Hasil pengukuran DO rata-rata dari ketiga stasiun berkisar antara 1,93-2,44 mg/L. Rendahnya hasil pengukuran DO diduga karena suhunya tinggi, dan juga karena banyak terdapat eceng gondok sehingga oksigen yang terlarut kedalam perairan tidak optimal. Menurut PP No. 82 tahun 2001 kadar DO yang optimal lebih dari $4 \mathrm{mg} / \mathrm{L}$, hal ini menunjukkan bahwa hasil pengukuran konsentrasi oksigen terlarut dapat dikatakan rendah dan jauh dari kebutuhan optimal bagi organisme perairan diduga karena pengaruh limbah cair yang masuk ke dalam perairan, baik limbah domestik maupun limbah batik.

\section{Kesimpulan}

Berdasarkan hasil penelitian mengenai Status Sedimen Sungai Bremi Kabupaten Pekalongan Ditinjau dari Aspek Kimia dan Biologi yang telah dilakukan dapat diambil kesimpulan sebagai berikut:

1. Konsentrasi kromium sebesar 3,395-8,768 ppm, konsentrasi fenol sebesar 0,035-0,0623 ppm, dan tekstur sedimen adalah lanau berpasir

2. Struktur komunitas makrobentos meliputi H' sebesar 0,687, E menunjukkan nilai sebesar 0,49, D didapatkan hasil sebesar 0,66 makrobentos yang ditemukan di Sungai Bremi adalah Chironomus sp, Nereis sp, Lymnaea sp, dan Tubifex sp. Kelimpahan individu makrobentos hanya terdapat di stasiun I sebesar $1270 \mathrm{ind} / \mathrm{m}^{3}$.

3. Hubungan antara konsentrasi kromium, fenol dengan struktur komunitas makrobentos di Sungai Bremi memiliki korelasi yang berkisar 0,617-0,797 yang kuat.

4. Status sedimen berdasarkan hasil konsentrasi kromium $(\mathrm{Cr})$, fenol dan struktur makrobentos dibandingkan dengan baku mutu sedimen menunjukkan status sedimen Sungai Bremi dalam keadaan tercemar.

\section{Ucapan Terima Kasih}

Ucapan terima kasih ditujukan kepada Dr. Ir. Frida Purwanti, M.Sc dan Dr. Ir. Haeruddin, M.Si atas bimbingannya dalam penulisan jurnal ini.

\section{DAFTAR PUSTAKA}

Anna, S. 2001. Model Pengelolaan Kawasan Pesisir dan Daerah Aliran Sungai Secara Terpadu. Makalah Falsafah Sains, Program Pasca Sarjana. Institut Pertanian Bogor. Bogor.

Apriadi, D. 2005. Kandungan Logam Berat $\mathrm{Hg}$, Pb, dan Cr pada Air, Sedimen dan Kerang Hijau (Perna viridis L.) di Peraiaran Kamal Muara, Teluk Jakarta. Institut Pertanian Bogor. Bogor.

Ariani, F., N. Syahril, dan I. S. Yusni. 2012. Analisis Kandungan Minyak Pada Air dan Sedimen di Perairan Sekitar Bungus Teluk Kabng Kota Padang Sumatera Barat. UNRI, Pekanbaru 
ATSDR (Agency for Toxic Substances and Disease Registry). 2006. Toxicological Profil fo Phenol. Atlanta, GA: U.S. Departement of Health and Human Services, Public Health Services.

Effendi, H. 2003. Telaah Kualitas Air Bagi Pengelolaan Sumberdaya dan Lingkungan Perairan. Kanisius. Yogyakarta.

Hadi, S. 2004. Metodologi Research. Andi, Yogyakarta, 300 - 303 hlm

Hasan, I. 2004. Analisis Data Penelitian dengan Statistik. Bumi Aksara. Bandung.

Kaban, S. dan Husnah.2010. Distribusi Plumbum dan Chromium dalam Sedimen dan Proffil Fisiko-Kimia Perairan Sungai Musi Sumatera Selatan. Balai Riset Perikanan Periaran Umum, Palembang. Prosiding Seminar Nasional Limnologi V.

Mutia, H 2007. Kualitas Fisika-Kimia Sedimen Serta Hubungannya terhadap Struktur Komunitas Hewan makrobentos di Estuari Percut Sei Tuan. Program Pasca Sarjana. Institut Pertanian Bogor. Bogor.

Nybakken, J.W. 1992. Biologi Laut : Suatu Pendekatan Ekologis. PT. Gramedia. Jakarta

Odum, E. P. 1996. Dasar-dasar Ekologi. Diterjemahkan oleh T. Samingan. Edisi Ketiga. Gajahmada University Press. Yogyakarta.

Rahmawati, I. Puspita, dan A. Nunik. 2008. Sistem Pengendalian Banjir Sungai Sengkarang (Normalisasi Sungai) (Flood Control System of Sengkarang River) [Tesis]. Fakultas Teknik Universitas Diponegoro. Semarang.

Sudaryanto, A. 2001. Struktur Komunitas Hewan makrobentos, dan Kondisi Fisiko Kimiawi Sedimen di Perairan Donan, Cilacap, Jawa Tengah. Jurnal Teknologi Lingkungan, 2(2):119-123

Ulfah, Y. 2012. Struktur Komunitas Makrozoobenthos di Perairan Wilayah Morosari Desa Bedono Kecamatan Sayung Demak. FPIK, Univeristas Diponegoro, Semarang.

Widadi, F. X. 2005. Identifikasi Senyawa Fenolik pada Ekstral Aloe Vera. Fakultas Pertanian. Universitas Tanjungpura. Pontianak.

Wiryanto. 1997. Pengaruh Limbah Cair Industri Tekstil PT. Tyfoundtex Indonesia, Kartasura, Sukoharjo Terhadap Perubahan DO, BOD, Suhu, pH, Logam, dan Plankton di Sungai Kudusan Sukoharjo DAN Premulung Surakarta. [Tesis]. Yogyakarta. Program Pasca Sarjana UGM. 